Supplement of Nat. Hazards Earth Syst. Sci., 16, 2287-2301, 2016

http://www.nat-hazards-earth-syst-sci.net/16/2287/2016/

doi:10.5194/nhess-16-2287-2016-supplement

(c) Author(s) 2016. CC Attribution 3.0 License.

(c) (1)

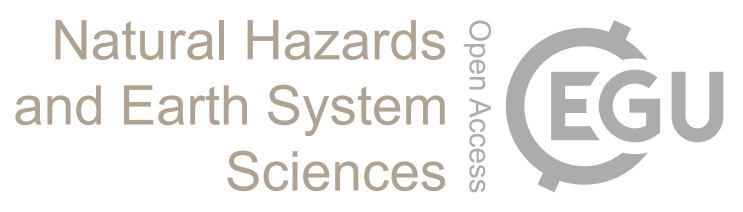

Supplement of

\title{
Towards thresholds of disaster management performance under demographic change: exploring functional relationships using agent-based modeling
}

Gunnar Dressler et al.

Correspondence to: Gunnar Dressler (gunnar.dressler@ufz.de)

The copyright of individual parts of the supplement might differ from the CC-BY 3.0 licence. 
Dressler et al.: Towards thresholds of disaster management performance under demographic change: exploring functional relationships using agent-based modelling. Supplement A: ODD+D Protocol

\begin{tabular}{|c|c|c|c|}
\hline \multicolumn{2}{|c|}{ Outline } & Guiding questions & Description \\
\hline \multirow[b]{4}{*}{$\frac{\sum_{0}^{3}}{\sum_{0}^{3}}$} & \multirow[t]{2}{*}{ I.i Purpose } & I.i.a What is the purpose of the study? & $\begin{array}{l}\text { The purpose of the model is to analyze the performance of disaster management and understand how it is } \\
\text { affected by change (e.g. demographic, climatic, or technological). There are three main questions: (1) Which } \\
\text { dimension of change has the most profound influence on the performance of disaster management? (2) Can we } \\
\text { identify bottlenecks or critical thresholds for the capacities of disaster management to ensure protection? (3) } \\
\text { How do these thresholds depend on the regional geographic and demographic setting? }\end{array}$ \\
\hline & & $\begin{array}{l}\text { I.ii.b For whom is the model } \\
\text { designed? }\end{array}$ & $\begin{array}{l}\text { The model is designed for both scientists and stakeholders, as an exploratory tool to understand the functioning } \\
\text { of disaster management under change and as a discussion tool to illustrate these results to experts, address } \\
\text { possible shortcomings and highlight options for improvement. }\end{array}$ \\
\hline & \multirow[t]{2}{*}{$\begin{array}{l}\text { I.ii Entities, state } \\
\text { variables, and scales }\end{array}$} & $\begin{array}{l}\text { I.ii.a What kinds of entities are in the } \\
\text { model? }\end{array}$ & $\begin{array}{l}\text { - There is a single type of agents (DMOs), each representing a unit or group of helpers of a disaster } \\
\text { management organization. } \\
\text { - The physical environment of the model is characterized by a map that includes a transportation network } \\
\text { (streets), rivers, flood prone areas and certain target sites as entities. }\end{array}$ \\
\hline & & $\begin{array}{l}\text { I.ii.b By what attributes (i.e. state } \\
\text { variables and parameters) are these } \\
\text { entities characterized? }\end{array}$ & $\begin{array}{l}\text { DMOs: } \\
\text { - } \quad \text { team-size: number of helpers associated to the group } \\
\text { - } \quad \text { sandbags-capacity: transportation capacity, i.e. number of sandbags that can be transported by this group in } \\
\text { one turn (corresponding to vehicle size) } \\
\text { - } \quad \text { moving-speed / speed-min / speed-limit: current moving speed as well as minimum and maximum speed of } \\
\text { the DMO vehicle } \\
\text { - } \quad \text { assigned-task: one of 'fill sandbags', 'transport sandbags', 'distribute sandbags' } \\
\text { - } \quad \text { information-access: partial knowledge / full knowledge } \\
\text { Disaster sites: } \\
\text { - } \quad \text { location: location of the site on the map and connection to the transportation network } \\
\text { - } \quad \text { sandbags-needed / sandbags-present / sandbags-distributed: respective number of sandbags needed in total } \\
\text { to fulfil the task, currently present, and already distributed at the site } \\
\text { - } \quad \text { fixed?: true/false, indicating whether all tasks at the site are fulfilled or not } \\
\text { Sandbag reserves: } \\
\text { - location: location of the site on the map and connection to the transportation network } \\
\text { - } \quad \text { number-sandbags-filled: current number of sandbags filled and present at the site } \\
\text { Transportation network: } \\
\text { - } \quad \text { street-type: one of 'primary', 'secondary', 'tertiary' or 'motorway' defining the type of the street } \\
\text { - } \quad \text { max-speed: speed limit, depending on street type } \\
\text { Rivers and flood prone areas: } \\
\text { - } \quad \text { location: location on the map }\end{array}$ \\
\hline
\end{tabular}


Dressler et al.: Towards thresholds of disaster management performance under demographic change: exploring functional relationships using agent-based modelling. Supplement A: ODD+D Protocol

\begin{tabular}{|c|c|c|}
\hline & $\begin{array}{l}\text { I.ii.c What are the exogenous factors } \\
\text { / drivers of the model? }\end{array}$ & $\begin{array}{l}\text { Different processes of change (e.g. demographic change, climate change) influence the system and thus the } \\
\text { model dynamics. These effects are included via certain parameters that are systematically varied, such as the } \\
\text { number of DMO agents } \mathrm{N}_{\mathrm{DMO}} \text { that can decrease as a consequence of demographic change. }\end{array}$ \\
\hline & $\begin{array}{l}\text { I.ii.d If applicable, how is space } \\
\text { included in the model? }\end{array}$ & $\begin{array}{l}\text { - The model is spatially explicit and uses GIS data as input for the location of rivers, flood prone areas as well } \\
\text { as the transportation network. }\end{array}$ \\
\hline & $\begin{array}{l}\text { I.ii.e What are the temporal and } \\
\text { spatial resolutions and extents of the } \\
\text { model? }\end{array}$ & $\begin{array}{l}\text { - Time: One time step (tick) represents one minute. There is no fixed time horizon as the model runs until all } \\
\text { tasks are finished. } \\
\text { - } \text { Space: The spatial extent corresponds to a defined region, e.g. a city, one grid cell has a resolution of } 40 \mathrm{~m} \\
\text { x } 40 \mathrm{~m}\end{array}$ \\
\hline $\begin{array}{l}\text { I.iii Process overview } \\
\text { and scheduling }\end{array}$ & $\begin{array}{l}\text { I.iii.a What entity does what, and in } \\
\text { what order? }\end{array}$ & $\begin{array}{l}\text { In each time step, the model checks first, whether all tasks are solved or not. If yes, the simulation stops, } \\
\text { otherwise it steps into the main routine that is executed for each DMO agent: } \\
\text { - At the beginning of the simulation each DMO gets assigned an initial task. In each subsequent time step, the } \\
\text { model checks if the DMO has an assigned task, if yes, it carries out that task, otherwise a new task will be } \\
\text { assigned. } \\
\text { - Depending on the assigned task, the DMO agent will either: } \\
\text { a) Fill sandbags, with a given rate, depending on the team-size of the DMO } \\
\text { b) Transport sandbags, which involves loading sandbags onto the vehicle, moving along the } \\
\text { c) Distributing sandbags at the disaster site, with a given rate, depending on the team-size of the DMO } \\
\text { At specified intervals, DMO agents will also check whether they should switch to another task, e.g. if more } \\
\text { capacity is needed to fill sandbags or to transport sandbags } \\
\text { The main routine of the model is also depicted in the following figure: }\end{array}$ \\
\hline
\end{tabular}


Dressler et al.: Towards thresholds of disaster management performance under demographic change: exploring functional relationships using agent-based modelling. Supplement A: ODD+D Protocol

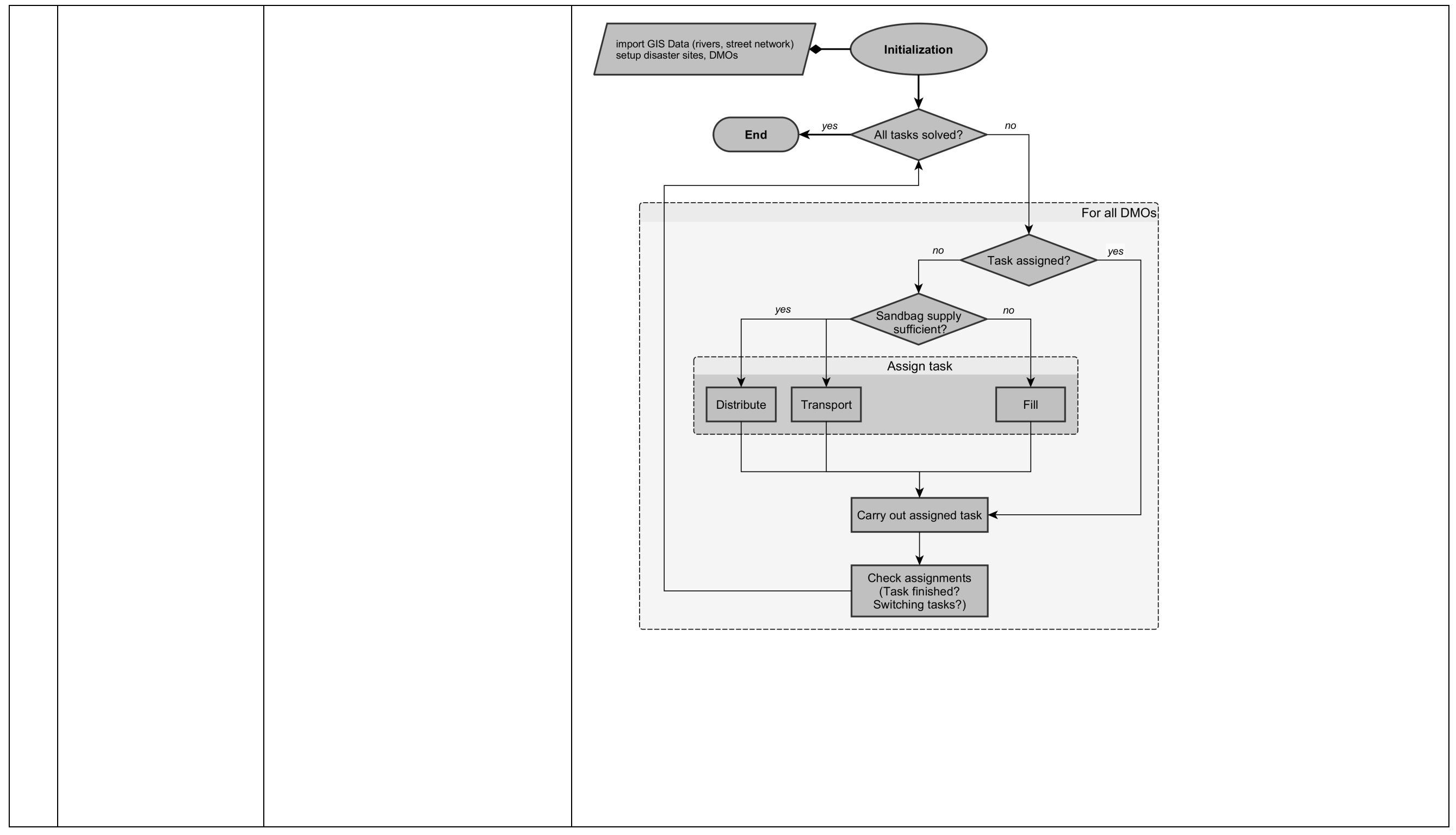


Dressler et al.: Towards thresholds of disaster management performance under demographic change: exploring functional relationships using agent-based modelling. Supplement A: ODD+D Protocol

\begin{tabular}{|c|c|c|c|}
\hline \multirow{6}{*}{ 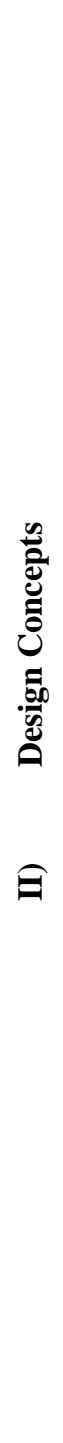 } & \multirow{5}{*}{$\begin{array}{l}\text { II.i Theoretical and } \\
\text { Empirical Background }\end{array}$} & $\begin{array}{l}\text { II.i.a Which general concepts, } \\
\text { theories or hypotheses are underlying } \\
\text { the model's design at the system } \\
\text { level or at the level(s) of the } \\
\text { submodel(s) (apart from the decision } \\
\text { model)? What is the link to } \\
\text { complexity and the purpose of the } \\
\text { model? }\end{array}$ & $\begin{array}{l}\text { - The model has been developed in order to depict the case of flood protection and disaster management in } \\
\text { Saxony, however its generality should facility the transferability to other settings, too. } \\
\text { - The model components are kept rather simple, as the model's purpose is to serve as a virtual lab, rather than } \\
\text { as a prediction tool. } \\
\text { - Complexity arises from the decision making of the agents and interaction between the agents and the model } \\
\text { environment. }\end{array}$ \\
\hline & & $\begin{array}{l}\text { II.i.b On what assumptions is/are the } \\
\text { agents' decision model(s) based? }\end{array}$ & DMO decision making is based on simple heuristics, e.g. "if-then” rules. \\
\hline & & $\begin{array}{l}\text { II.i.c Why is a/are certain decision } \\
\text { model(s) chosen? }\end{array}$ & $\begin{array}{l}\text { Under disaster conditions, DMOs rarely have the time to derive an optimal decision and have to rely rather on } \\
\text { certain routines, past experiences or ad-hoc decisions. Therefore we employ simple "if-then" rules rather than } \\
\text { more complicated optimization algorithms. }\end{array}$ \\
\hline & & $\begin{array}{l}\text { II.i.d If the model / a submodel (e.g. } \\
\text { the decision model) is based on } \\
\text { empirical data, where does the data } \\
\text { come from? }\end{array}$ & $\begin{array}{l}\text { - The spatial setting of the model (rivers, flood prone areas, street network) is based on freely available GIS } \\
\text { data. } \\
\text { - Some decision making rules and their parameters are based on basic rules / guides used by disaster } \\
\text { management organisations for flood protection. }\end{array}$ \\
\hline & & $\begin{array}{l}\text { II.i.e At which level of aggregation } \\
\text { were the data available? }\end{array}$ & - $\quad$ GIS data were available at a local (e.g. city) level. \\
\hline & $\begin{array}{l}\text { II.ii Individual Decision } \\
\text { Making }\end{array}$ & $\begin{array}{l}\text { II.ii.a What are the subjects and } \\
\text { objects of decision-making? On } \\
\text { which level of aggregation is } \\
\text { decision-making modeled? Are } \\
\text { multiple levels of decision making } \\
\text { included? }\end{array}$ & $\begin{array}{l}\text { - DMO units are the subject of decision making. } \\
\text { - The object of decision making is the execution of tasks (filling, transporting, distributing sandbags) at } \\
\text { certain target sites. } \\
\text { - } \quad \text { There is only one level of decision making. }\end{array}$ \\
\hline
\end{tabular}


Dressler et al.: Towards thresholds of disaster management performance under demographic change: exploring functional relationships using agent-based modelling. Supplement A: ODD+D Protocol

\begin{tabular}{|c|c|c|}
\hline & $\begin{array}{l}\text { II.ii.b What is the basic rationality } \\
\text { behind agents' decision-making in } \\
\text { the model? Do agents pursue an } \\
\text { explicit objective or have other } \\
\text { success criteria? }\end{array}$ & $\begin{array}{l}\text { - } \quad \text { Agents follow certain heuristics when making decisions, based on the level of information available to them. } \\
\text { - } \quad \text { Their objective is to fulfil all tasks at all target sites in a preferably short amount of time. }\end{array}$ \\
\hline & $\begin{array}{l}\text { II.ii.c How do agents make their } \\
\text { decisions? }\end{array}$ & See II.ii.b or III.iv.a for details. \\
\hline & $\begin{array}{l}\text { II.ii.d Do the agents adapt their } \\
\text { behavior to changing endogenous and } \\
\text { exogenous state variables? And if } \\
\text { yes, how? }\end{array}$ & $\begin{array}{l}\text { Yes. Agents can switch between tasks, when the need arises, e.g. when tasks at a specific disaster site are } \\
\text { fulfilled, DMOs can switch to a different site or when sandbag supply at the filling site is running low, agents } \\
\text { can switch from transporting/distributing sandbags to sandbag filling. }\end{array}$ \\
\hline & $\begin{array}{l}\text { II.ii.e Do social norms or cultural } \\
\text { values play a role in the decision- } \\
\text { making process? }\end{array}$ & No. \\
\hline & $\begin{array}{l}\text { II.ii.f Do spatial aspects play a role in } \\
\text { the decision process? }\end{array}$ & Yes. The current location of the DMO agents and the distance to target sites is incorporated into their decision. \\
\hline & $\begin{array}{l}\text { II.ii.g Do temporal aspects play a role } \\
\text { in the decision process? }\end{array}$ & DMO agents make decisions based only on the current state of the system. \\
\hline & $\begin{array}{l}\text { II.ii.h To which extent and how is } \\
\text { uncertainty included in the agents' } \\
\text { decision rules? }\end{array}$ & Uncertainty is not included in the decision making. \\
\hline II.iii Learning & $\begin{array}{l}\text { II.iii.a Is individual learning included } \\
\text { in the decision process? How do } \\
\text { individuals change their decision } \\
\text { rules over time as consequence of } \\
\text { their experience? }\end{array}$ & No, learning is not included. \\
\hline & $\begin{array}{l}\text { II.iii.b Is collective learning } \\
\text { implemented in the model? }\end{array}$ & No. \\
\hline II.iv Individual Sensing & $\begin{array}{l}\text { II.iv.a What endogenous and } \\
\text { exogenous state variables are }\end{array}$ & $\begin{array}{l}\text { - DMO agents have full knowledge about the spatial settings of the model (transportation network, location of } \\
\text { all target sites). }\end{array}$ \\
\hline
\end{tabular}


Dressler et al.: Towards thresholds of disaster management performance under demographic change: exploring functional relationships using agent-based modelling. Supplement A: ODD+D Protocol

\begin{tabular}{|c|c|c|}
\hline & $\begin{array}{l}\text { individuals assumed to sense and } \\
\text { consider in their decisions? Is the } \\
\text { sensing process erroneous? }\end{array}$ & $\begin{array}{l}\text { - Each DMO agent has a certain level of information access about the state of each site: } \\
\text { a) Full knowledge: complete knowledge about the state of all disaster sites at all times. } \\
\text { b) Partial knowledge: knowledge can only be acquired through direct contact, i.e. when they are at a } \\
\text { site, and will be remembered from then onwards. } \\
\text { - The sensing is not erroneous. }\end{array}$ \\
\hline & $\begin{array}{l}\text { II.iv.b What state variables of which } \\
\text { other individuals can an individual } \\
\text { perceive? Is the sensing process } \\
\text { erroneous? }\end{array}$ & DMO agents are not able to sense the state variables of other agents. \\
\hline & $\begin{array}{l}\text { II.iv.c What is the spatial scale of } \\
\text { sensing? }\end{array}$ & DMO agents have full spatial knowledge. \\
\hline & $\begin{array}{l}\text { II.iv.d Are the mechanisms by which } \\
\text { agents obtain information modeled } \\
\text { explicitly, or are individuals simply } \\
\text { assumed to know these variables? }\end{array}$ & Agents are assumed to know the values of the sensed variables. \\
\hline & $\begin{array}{l}\text { II.iv.e Are costs for cognition and } \\
\text { costs for gathering information inclu- } \\
\text { ded in the model? }\end{array}$ & No. \\
\hline \multirow{3}{*}{$\begin{array}{l}\text { II.v Individual } \\
\text { Prediction }\end{array}$} & $\begin{array}{l}\text { II.v.a Which data uses the agent to } \\
\text { predict future conditions? }\end{array}$ & Agents do not predict future conditions. \\
\hline & $\begin{array}{l}\text { II.v.b What internal models are } \\
\text { agents assumed to use to estimate } \\
\text { future conditions or consequences of } \\
\text { their decisions? }\end{array}$ & Not applicable. \\
\hline & $\begin{array}{l}\text { II.v.c Might agents be erroneous in } \\
\text { the prediction process, and how is it } \\
\text { implemented? }\end{array}$ & Not applicable. \\
\hline II.vi Interaction & $\begin{array}{l}\text { II.vi.a Are interactions among agents } \\
\text { and entities assumed as direct or } \\
\text { indirect? }\end{array}$ & $\begin{array}{l}\text { Interaction between DMO agents is indirect as they perceive the status of the target sites (disaster sites/sandbag } \\
\text { reserve) and can adapt their behavior based on the actions of other agents at these sites. }\end{array}$ \\
\hline
\end{tabular}


Dressler et al.: Towards thresholds of disaster management performance under demographic change: exploring functional relationships using agent-based modelling. Supplement A: ODD+D Protocol

\begin{tabular}{|c|c|c|}
\hline & $\begin{array}{l}\text { II.vi.b On what do the interactions } \\
\text { depend? }\end{array}$ & Interaction does not depend on any parameters/conditions. \\
\hline & $\begin{array}{l}\text { II.vi.c If the interactions involve } \\
\text { communication, how are such } \\
\text { communications represented? }\end{array}$ & Not applicable. \\
\hline & $\begin{array}{l}\text { II.vi.d If a coordination network } \\
\text { exists, how does it affect the agent } \\
\text { behaviour? Is the structure of the } \\
\text { network imposed or emergent? }\end{array}$ & $\begin{array}{l}\text { In the current model version, DMO agents act independently to solve their tasks. A coordination between of } \\
\text { tasks between agents is planned. }\end{array}$ \\
\hline \multirow[t]{2}{*}{ II.vii Collectives } & $\begin{array}{l}\text { II.vii.a Do the individuals form or } \\
\text { belong to aggregations that affect, } \\
\text { and are affected by, the individuals? } \\
\text { Are these aggregations imposed by } \\
\text { the modeller or do they emerge } \\
\text { during the simulation? }\end{array}$ & Agents do not form collectives in the current model version. \\
\hline & $\begin{array}{l}\text { II.vii.b How are collectives } \\
\text { represented? }\end{array}$ & Not applicable. \\
\hline \multirow{2}{*}{ II.viii Heterogeneity } & $\begin{array}{l}\text { II.viii.a Are the agents } \\
\text { heterogeneous? If yes, which state } \\
\text { variables and/or processes differ } \\
\text { between the agents? }\end{array}$ & Currently, within any single simulation all DMO agents are homogeneous in their properties. \\
\hline & $\begin{array}{l}\text { II.viii.b Are the agents heterogeneous } \\
\text { in their decision-making? If yes, } \\
\text { which decision models or decision } \\
\text { objects differ between the agents? }\end{array}$ & No. \\
\hline II.ix Stochasticity & $\begin{array}{l}\text { II.ix.a What processes (including } \\
\text { initialization) are modeled by } \\
\text { assuming they are random or partly } \\
\text { random? }\end{array}$ & $\begin{array}{l}\text { - } \quad \text { Disaster sites are randomly distributed at the beginning of each simulation. } \\
\text { The order in which DMO agents act in each time step is determined randomly by the Netlogo 'ask' } \\
\text { command. }\end{array}$ \\
\hline
\end{tabular}


Dressler et al.: Towards thresholds of disaster management performance under demographic change: exploring functional relationships using agent-based modelling. Supplement A: ODD+D Protocol

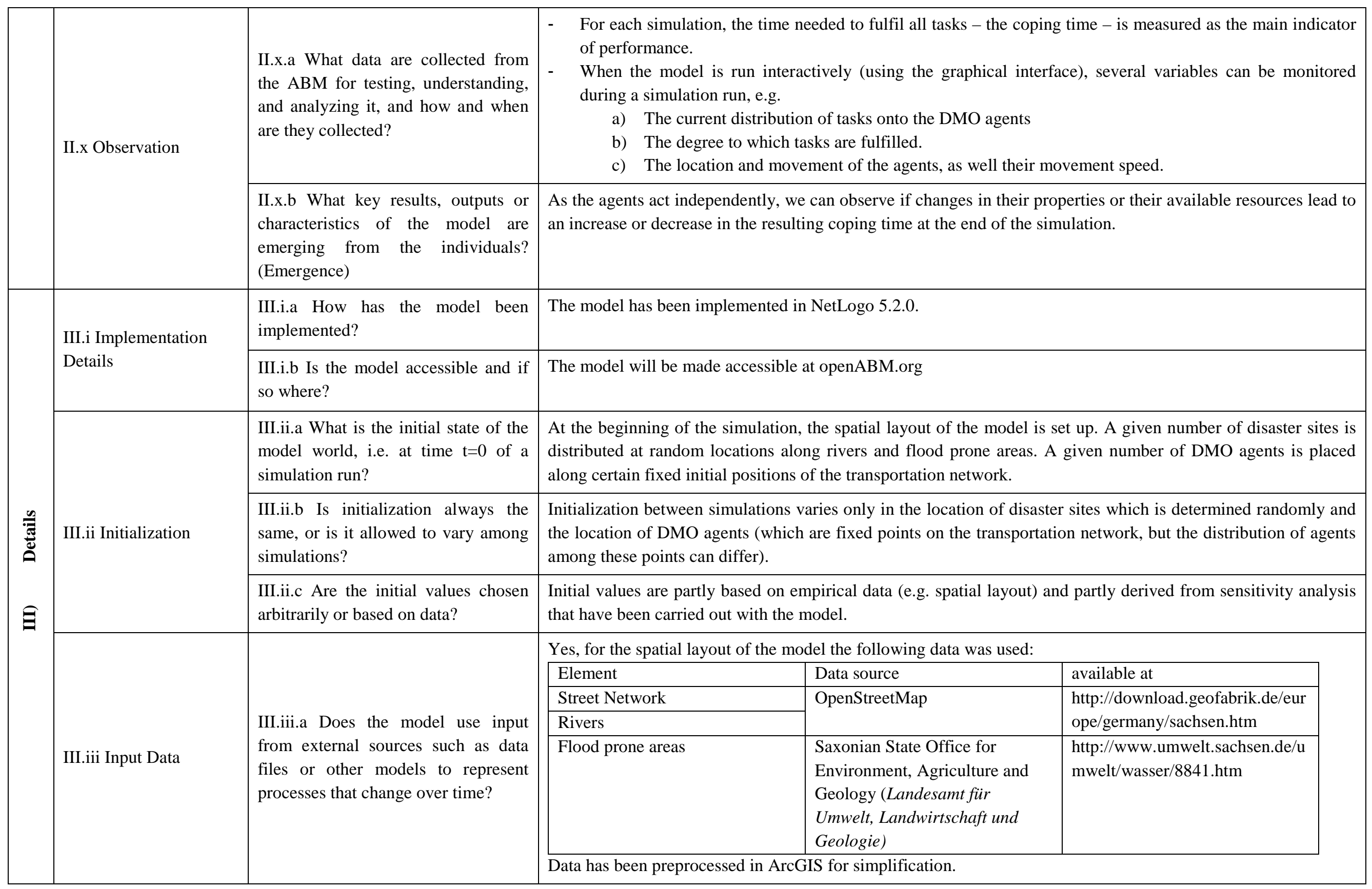


Dressler et al.: Towards thresholds of disaster management performance under demographic change: exploring functional relationships using agent-based modelling. Supplement A: ODD+D Protocol

\begin{tabular}{|c|c|c|}
\hline III.iv Submodels & $\begin{array}{l}\text { III.iv.a What, in detail, are the } \\
\text { submodels that represent the } \\
\text { processes listed in 'Process overview } \\
\text { and scheduling'? }\end{array}$ & 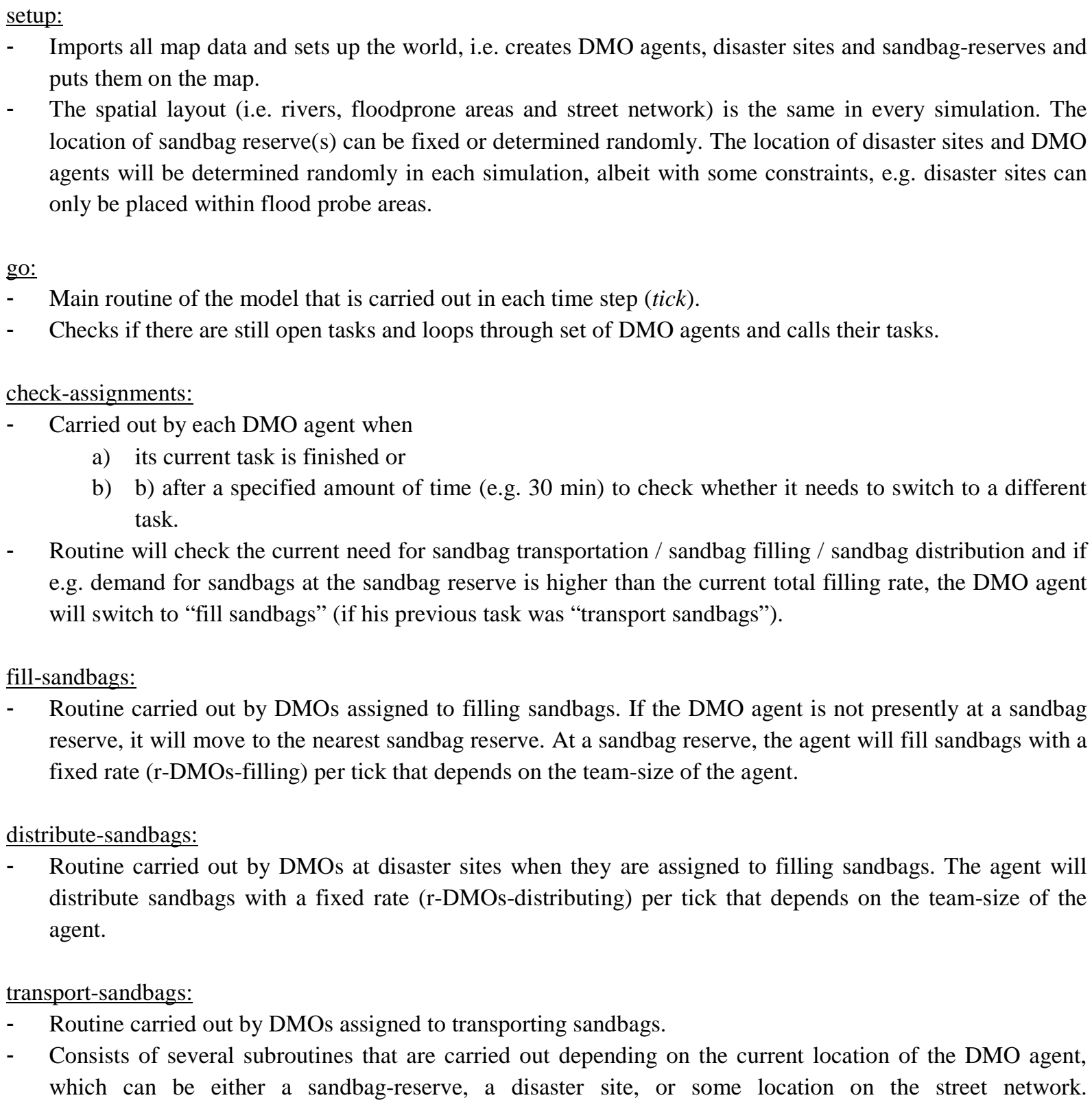 \\
\hline
\end{tabular}


Dressler et al.: Towards thresholds of disaster management performance under demographic change: exploring functional relationships using agent-based modelling. Supplement A: ODD+D Protocol

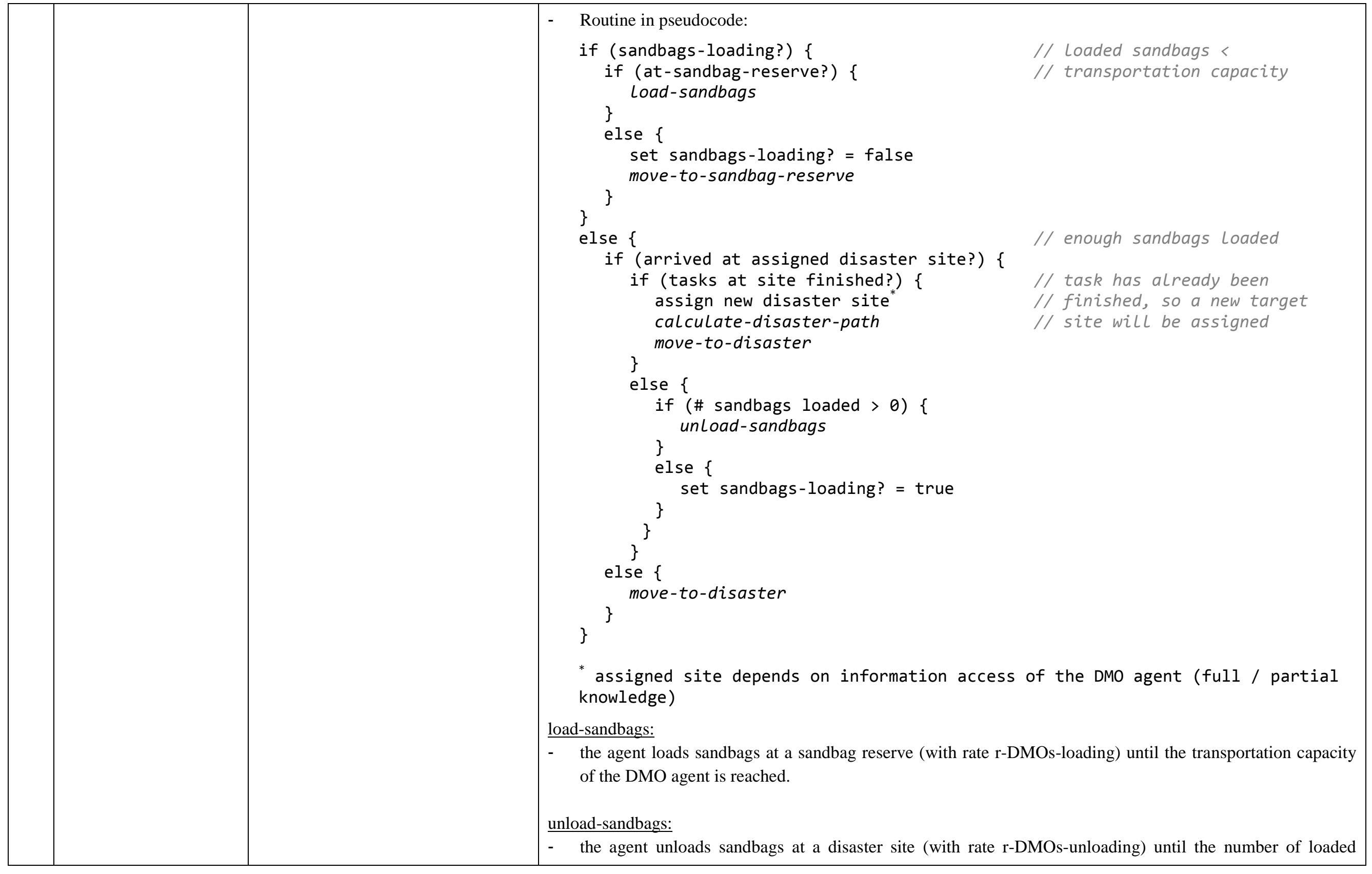


Dressler et al.: Towards thresholds of disaster management performance under demographic change: exploring functional relationships using agent-based modelling. Supplement A: ODD+D Protocol

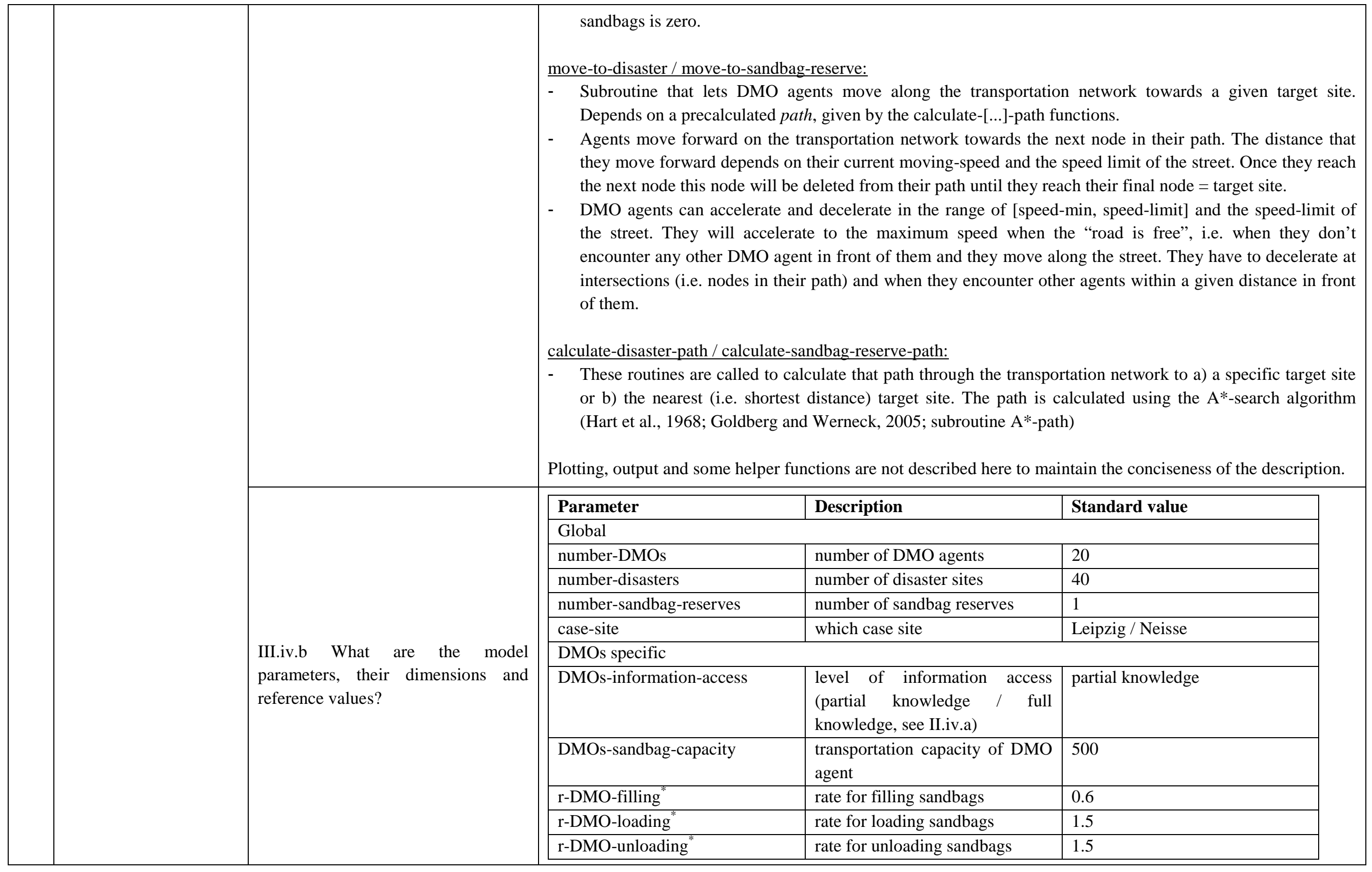


Dressler et al.: Towards thresholds of disaster management performance under demographic change: exploring functional relationships using agent-based modelling. Supplement A: ODD+D Protocol

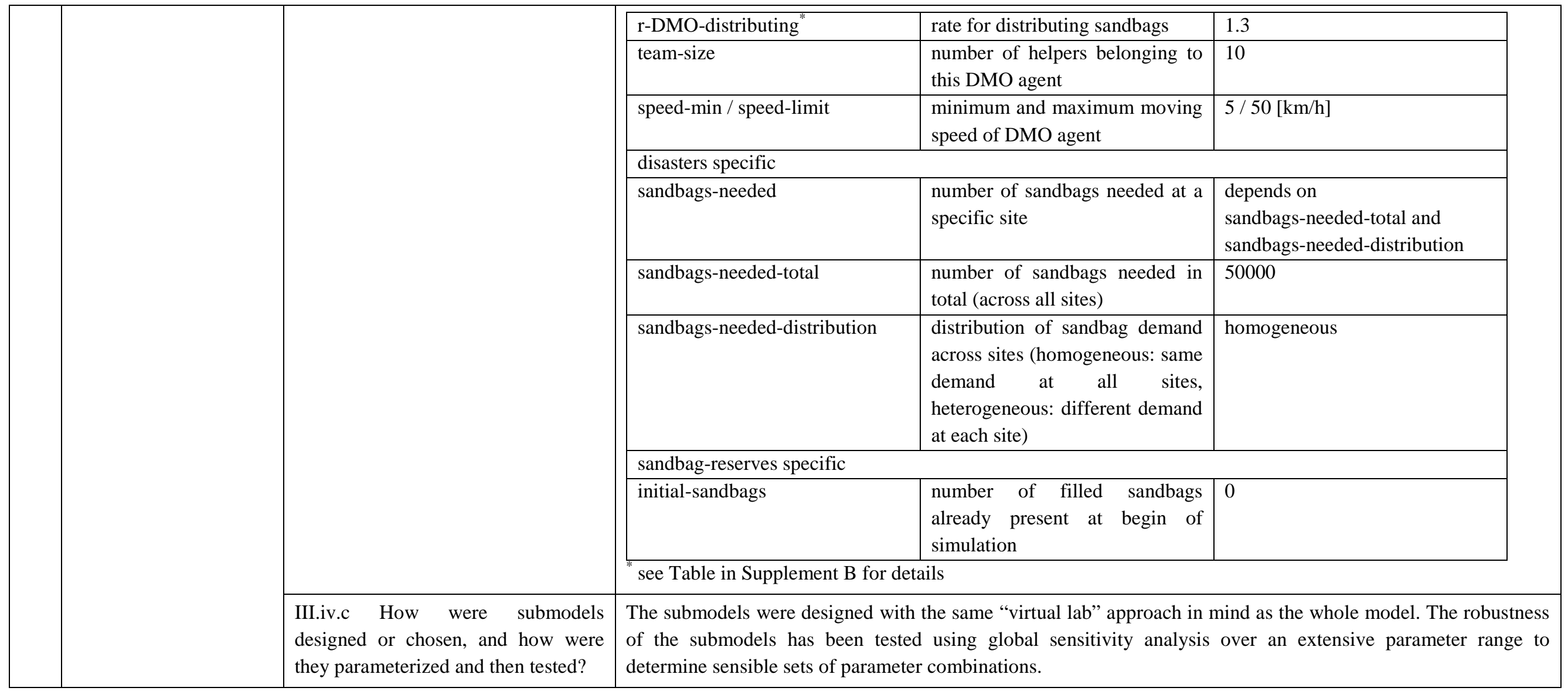

\section{References}

Goldberg, A. V. and Werneck, R. F. F.: Computing Point-to-Point Shortest Paths from External Memory., in SIAM Workshop on Algorithms Engineering and Experimentation (ALENEX 05), pp. 26-40., 2005.

Hart, P. E., Nilsson, N. J. and Raphael, B.: A formal basis for the heuristic determination of minimum cost paths, Syst. Sci. Cybern. IEEE Trans., 4(2), 100107, 1968. 
Dressler et al.: Towards thresholds of disaster management performance under demographic change: exploring functional relationships using agent-based modelling. Supplement B: Model assumptions

\begin{tabular}{|c|c|c|c|c|c|c|c|}
\hline Model task & \multicolumn{4}{|l|}{ Assumption } & Source & \multicolumn{2}{|c|}{ Model parameter } \\
\hline \multirow[t]{2}{*}{ Sandbag filling } & \multicolumn{4}{|c|}{$\begin{array}{l}\text { Filling rate for sandbags: } \\
\text { - } \quad \text { Average: } 40-60 \text { sandbags per helper per hour } \\
\text { - } \quad \text { Trained helpers: } 80 \text { sandbags per helper per hour }\end{array}$} & $\begin{array}{l}\text { [1] Taschenkarte Deichverteidigung, } \\
\text { THW Ortsverband Emden, as of 12/2007, } \\
\text { obtainable from www.deichverteidigung.de }\end{array}$ & \multicolumn{2}{|c|}{$\begin{array}{l}r_{\text {filling }} \\
=[0.6,1.2] S \times H \times \min ^{-1} \\
=[36,72] S \times H \times \mathrm{h}^{-1}\end{array}$} \\
\hline & \multicolumn{4}{|c|}{$\begin{array}{l}\text { Filling via funnel and tying sandbags: } \\
\text { - } \quad 180 \text { sandbags per hour in a group of } 5-6 \text { helpers } \\
\quad \approx 30 \text {-36 sandbags per hour per helper }\end{array}$} & $\begin{array}{l}\text { [2] Umgang mit Sandsäcken und deren } \\
\text { Verwendung, Udo Wawerek THW Ortsverband } \\
\text { Dinslaken }\end{array}$ & \multicolumn{2}{|c|}{$\begin{array}{l}S \text { - Sandbags } \\
H \text { - Helper }\end{array}$} \\
\hline \multirow[t]{2}{*}{$\begin{array}{l}\text { Sandbag loading / } \\
\text { unloading }\end{array}$} & \multicolumn{4}{|c|}{$\begin{array}{l}\text { Loading / unloading from truck (by hand): } \\
\text { - } \quad \text { If distance to truck }<10 \mathrm{m:} 80 \text { sandbags per helper per hour }\end{array}$} & {$[2]$} & \multirow{2}{*}{\multicolumn{2}{|c|}{$\begin{array}{l}r_{\text {loading }} / r_{\text {unloading }} \\
=[1.0,2.0] S \times \mathrm{min}^{-1} \\
=[60,120] S \times \mathrm{Hxh}^{-1}\end{array}$}} \\
\hline & \multicolumn{4}{|c|}{$\begin{array}{l}\text { Loading / unloading (palettes): } \\
\text { - } \quad \text { If filled sandbags are directly stored on palettes ( 50-70 Sandbags per } \\
\text { palette), they can be loaded much faster }\end{array}$} & [1], estimated value & & \\
\hline $\begin{array}{l}\text { Sandbag } \\
\text { distribution }\end{array}$ & \multicolumn{4}{|c|}{$\begin{array}{l}\text { Distribution at target site (i.e. dike): } \\
-\quad 80 \text { sandbags per helper per hour }\end{array}$} & {$[1]$} & \multicolumn{2}{|c|}{$\begin{array}{l}r_{\text {distributing }} \\
=[1.0,1.3] S \times H \times \min ^{-1} \\
=[60,78] S \times H \times \mathrm{h} \mathrm{h}^{-1}\end{array}$} \\
\hline \multirow[t]{8}{*}{ Transportation } & \multicolumn{4}{|c|}{$\begin{array}{l}\text { Transportation capacities: } \\
-\quad \text { calculated from average sandbag weight of } 15-20 \mathrm{~kg} \text { [1] }\end{array}$} & $\begin{array}{l}\text { Various technical specifications: } \\
\text { - } \quad \text { [3] THW Hamburg Nord http://www.thw- }\end{array}$ & \multirow{4}{*}{\multicolumn{2}{|c|}{$\begin{array}{l}D M O_{\text {Capacity }} \in\{250,500,1000 \\
2000\} \text { sandbags per DMO unit }\end{array}$}} \\
\hline & \multirow{2}{*}{\multicolumn{2}{|c|}{ Type }} & \multicolumn{2}{|c|}{ Loading capacity } & hamburg-nord.de/kfz/fgr-hang1.htm & & \\
\hline & & & Weight [t] & Sandbags & - [4] PrimoCargo & & \\
\hline & \multicolumn{2}{|c|}{$\begin{array}{l}\text { Transporter } \\
\text { Small truck (e.g. „Unimog”) } \\
\text { Large truck } \\
\text { Lowloader }\end{array}$} & $\begin{array}{c}1-2 \\
3-7 \\
10-15 \\
20-40 \\
\end{array}$ & $\begin{array}{c}50-120 \\
200-400 \\
500-1000 \\
1000-2500 \\
\end{array}$ & $\begin{array}{l}\text { http://www.primocargo.de/deutsch/ } \\
\text { medien/info-pool//kw-auflieger } \\
\text { - [5] Der Unimog 300/U400/U500. Technik. } \\
\text { Fakten. Daten. DaimlerChrysler AG, } \\
\text { http://www.mercedes-benz.com/unimog }\end{array}$ & & \\
\hline & \multicolumn{4}{|c|}{ Vehicle speed / speed limits: } & \multirow{4}{*}{$\begin{array}{l}\text { [6] Straßenverkehrs-Ordnung (StVO): } \\
\text { § } 3 \text { Geschwindigkeit, § } 18 \text { Autobahnen und } \\
\text { Kraftfahrstraßen, http://www.gesetze-im- } \\
\text { internet.de/bundesrecht/stvo_2013/gesamt.pdf }\end{array}$} & \multicolumn{2}{|c|}{ Speed limits per street type } \\
\hline & Type & Motorway & $\begin{array}{l}\text { Outside built- } \\
\text { up areas }\end{array}$ & $\begin{array}{l}\text { Inside built-up } \\
\text { areas }\end{array}$ & & \multirow{2}{*}{$\begin{array}{l}\text { Type } \\
\text { motorway } \\
\text { primary } \\
\text { secondary } \\
\text { tertiary } \\
2\end{array}$} & $\begin{array}{l}\text { Speed limit } \\
80 \mathrm{~km} / \mathrm{h}\end{array}$ \\
\hline & $\begin{array}{l}\text { Car / transporter } \\
{[<3.5 \mathrm{t}]} \\
\text { Truck }[3.5-7.5 \mathrm{t}]\end{array}$ & $130 \mathrm{~km} / \mathrm{h}^{1}$ & $100 \mathrm{~km} / \mathrm{h}$ & $50 \mathrm{~km} / \mathrm{h}$ & & & $\begin{array}{l}60 \mathrm{~km} / \mathrm{h} \\
50 \mathrm{~km} / \mathrm{h} \\
50 \mathrm{~km} / \mathrm{h} \\
30 \mathrm{~km} / \mathrm{h}\end{array}$ \\
\hline & $\begin{array}{l}\text { Truck / lowloader } \\
{[>7.5 \mathrm{t}]} \\
\frac{{ }^{1} \text { recommend maxim }}{}\end{array}$ & $80 \mathrm{~km} / \mathrm{h}$ & $60 \mathrm{~km} / \mathrm{h}$ & $50 \mathrm{~km} / \mathrm{h}$ & & \multicolumn{2}{|c|}{$\begin{array}{l}2 \text { assumed as residential areas with } \\
30 \mathrm{~km} / \mathrm{h} \text { zones }\end{array}$} \\
\hline
\end{tabular}

